\title{
Susceptibility of Koi, KoixRed Common Carp, and Red Common CarpxKoi to Koi Herpesvirus (KHV)
}

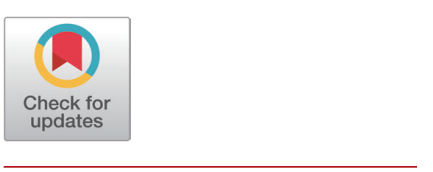

Received: October 3, 2020 Revised: October 14, 2020 Accepted: October 25, 2020

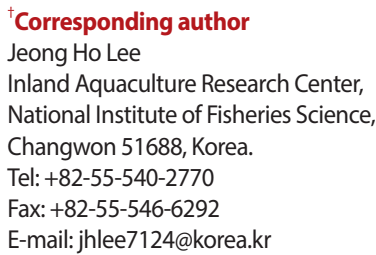

Copyright $\odot 2020$ The Korean Society of Developmental Biology.

This is an Open Access article distributed under the terms of the Creative Commons Attribution Non-Commercial License (http://creativecommons.org/licenses/ by-nc/4.0/) which permits unrestricted non-commercial use, distribution, and reproduction in any medium, provided the original work is properly cited.

ORCID

Ju-Ae Hwang

https://orcid.org/0000-0002-7144-3162 Jung Eun Kim

https://orcid.org/0000-0003-4769-9093 Hyeong Su Kim

https://orcid.org/0000-0003-3189-3844 Junseong Park

https://orcid.org/0000-0002-7526-660X Jeong-Ho Lee

https://orcid.org/0000-0002-2236-3748

Conflict of interests

The authors declare no potential conflict of interest.

Acknowledgements

This research was funded by project (R2020002) of the National Institute of

Fisheries Science, Korea.

\section{Authors' contributions}

Conceptualization: Lee $\mathrm{JH}$.

Data curation: Hwang JA

Formal analysis: Park JS.

Methodology: Hwang JA.

Validation: Kim HS.

\author{
Ju-Ae Hwang, Jung Eun Kim, Hyeong Su Kim, Junseong Park, and 'Jeong-Ho Lee \\ Inland Aquaculture Research Center, National Institute of Fisheries Science (NIFS), Changwon 51688, Korea
}

\section{Abstract}

The disease-causing koi herpes virus (KHV), also known as cyprinid herpesvirus-3 (CyHV3 ), causes mass mortality of koi and carp. Koi (Cyprinus carpio) is a host for KHV, one of 12 virus species in the Alloherpesviridae family. We examined the effects of KHV disease koi (KK), and on koixred common carp (KR) and red common carpxkoi (RK) cross, using a virus challenge test. The infected fish had clinical signs that included gill necrosis and skin lesions. The RK and KR were highly more resistant (cumulative mortality: RK; 6\% and KR; $8 \%$ ) to KHV infection than KK fish (cumulative mortality: $28 \%$ ). KHV DNA was confirmed in the tissues of all dead fish in groups by use of polymerase chain reaction (PCR), and the presence of the KHV protein in kidney was confirmed by immunohistochemistry. Histological analysis showed severe gill lesions and fusion of the lamellae in KK fish, but less severe damage in RK fish. In immunohistochemistry analysis, the KHV protein localized in the cytoplasm of infected kidney cells of KK, but the cross groups had lower levels of KHV antigen. Our data indicate that the cross groups had increased resistance to KHV disease.

Keywords: Koi, Breeding, Koi herpes virus (KHV), Gill, Kidney

\section{INTRODUCTION}

Many different species of herpesviruses can infect and cause diseases in mammals, birds, amphibians, reptiles, and fish (Roizman \& Pellet, 2001; Hedrick et al., 2006). According to the recent classification of the International Committee on Taxonomy of Viruses (ICTV; www.ictvonline. org), there are currently 3 families in the Herpesvirales order: Alloherpesviridae, Herpesviridae, and Malacoherpesviridae. The Alloherpesviridae has 12 species koi herpesvirus (KHV), also known as Cyprinid herpesvirus 3 (CyHV-3). This species has double strand DNA and a 295-kb genome (Aoki et al., 2007). The symptoms of infection are loss of swimming coordination, apathy, gathering at water inlets, necrosis of the gill, and sunken eyes (Hedrick et al., 2005). These infections have led to considerable economic losses (Hedrick et al., 2000).

In an initial study, researchers suggested that the gills are the major organ of virus entry in carp (Gilad et al., 2004; Dishon et al., 2005), but a more recent study demonstrated that the skin covering the body of fish is a major portal of KHV entry (Costes et al., 2009). After entry, the virus spreads to the kidney, spleen, and liver and high levels of KHV DNA can detect in these internal organs. Virus replication occurs in the gills, intestine, liver, brain, and kidneys (Pikarsky et al., 2004). 
Investigation: Kim JE.

Writing - original draft: Hwang JA.

Writing - review \& editing: Lee $\mathrm{JH}$.

\section{Ethics approval}

This study was carried out under the permission (2017-NIFS-IACUC-13) from the National Institute of Fisheries Science (NIFS), Korea.
There is evidence of KHV in wild and farmed fish worldwide. In Asia, there are reports of this virus in fish cultured in Japan (Sano et al., 2004), Taiwan (Tu et al., 2004; Cheng et al., 2011), China (Dong et al., 2011), Iran (Rahmati-Holasoo et al., 2016), and Korea (Gomez et al., 2011; Cho et al., 2014). KHV can be detected by a polymerase chain reaction (PCR) assay, an enzymelinked immunosorbent assay (ELISA) or immunohistochemical (IHC) methods (Akoi et al., 2011) in carp and koi (Sano et al., 2005; Haramoto et al., 2009; Akoi et al., 2011 \& Minamoto et al., 2012). Since 2007, the World Organization of Animal Health (OIE) has designated KHV as a statutory infectious disease. Infections by this virus have adversely affected the production and trade of koi and common carp (Haenen et al., 2004; Sano et al., 2004).

Fish of all ages appear susceptible to KHV (Bretzinger et al., 1999; Sano et al., 2004), but those weighing 2.5-6 g are more susceptible those weighing $230 \mathrm{~g}$ under experimental conditions. The gold fish $\times$ common carp hybrid has low susceptibility to this virus, with a mortality rate of only $5 \%$ (Hedrick et al., 2005). Approaches to control and prevent KHV infections mainly rely on avoiding exposure, because a safe and effective vaccine and chemotherapy are not currently available. For this reason, some researchers have proposed breeding for increased resistance to KHV infection (Hedrick et al., 2005). Thus, there is now evidence of differential resistance to KHV among different carp hybrids (Hedrick et al., 2005).

Red common carp (C. carpio) is a well-known breed of common carp that is widely used for crossbreeding and hybridization in China (Wang et al., 2006). In this study, we report the first cross breeding of koi (C. carpio) and red common carp (C. carpio) and then compared the susceptibility of these koi hybrids to experimental injections of KHV.

\section{MATERIALS AND METHODS}

\section{Fish}

Koi (Cyprinus carpio) and red common carp (Cyprinus carpio) broodstocks without any disease were reared and used for breeding experiments at the Inland Aquaculture Research Center, National Institute of Fisheries Science (Changwon, Korea). Ovulated eggs of koi were stripped and fertilized with sperm from koi and red common carp below the Table 1. Fish were used for the virus challenge test at the age of 10 months, when they weighed 9-12 $\mathrm{g}$.

After a 2 week adaptation in a re-circulation tank at $23^{\circ} \mathrm{C}$, the fish were used for infection trials.

\section{Virus infection}

The KHV strain F347 (VR-1592) was purchased from American Type Culture Collection (ATCC). The virus was incubated in common carp brain (CCB) cells. The CCB cell line was maintained at $23^{\circ} \mathrm{C}$ in minimum essential medium (MEM, Sigma-Aldrich, St. Louis, MO, USA) and supplemented with 10\% fetal bovine serum (FBS, Sigma-Aldrich), $2 \mathrm{mM}$ L-glutamine, 100 $\mathrm{IU} \mathrm{mL} \mathrm{m}^{-1}$ penicillin, and $100 \mu \mathrm{g} \mathrm{mL} \mathrm{m}^{-1}$ streptomycin (Sigma-Aldrich) for 14 days. The presence of CyHV-3 was evaluated by the presence of characteristic cytopathic effects and was confirmed by PCR (OIE, 2013). After titration, the virus was adjusted to a final concentration of $10^{4} 50 \%$ tissue culture infectious dose (TCID50) per $\mathrm{mL}^{-1}$ for intraperitoneal injection. The experiments were

Table 1. Koi and red common carp breeding combination

\begin{tabular}{cccc}
\hline \hline \multicolumn{3}{c}{ Parental combination } \\
\hline $\begin{array}{c}\text { Group } \\
\text { ratio }\end{array}$ & Koi×koi (KK) & Koixred common carp (KR) & Red common carp $\times$ koi (RK) \\
\hline
\end{tabular}


performed in triplicate aquaria with 4 groups ( $\mathrm{n}=50)$ : KK (koixkoi), KR (koixred common carp), and RK (red common carpxred common carp), and uninfected fish (control). There were 150 fish per group ( $\mathrm{n}=50 / \operatorname{tank})$ and total 600 fish used in this study. Fish were infected by intraperitoneal injection, and kept at $23^{\circ} \mathrm{C}$, and the control group was treated with saline. Fish were fed on a pellet diet and fish were observed daily for signs of disease and mortality for 45 days. Moribund fish were euthanized with an overdose of MS-222 and at the end of the 45 day period, all surviving fish were euthanized with an overdose of MS-222. Gill and kidney were sampled at 6 days and 9 days post injection, and died fish from each group until the end of the experiment. All tests were performed in gill and kidney (viral detection by PCR, histology analysis).

\section{Histological analysis}

For histopathology and immunohistochemistry (IHC), kidneys and gills were collected $(n=5)$ from each group on days 6 and days 9 , and fixed in 4\% neutral formalin for 24 h. Paraffinembedded tissues were stained with hematoxylin and eosin $(\mathrm{H} \& \mathrm{E})$ for histological observation, and analyzed by IHC staining. For IHC, heat-induced antigen retrieval was performed using 0.01 $\mathrm{M}$ sodium citrate buffer in a microwave for $15 \mathrm{~min}$. After quenching of endogenous peroxidase and blocking in $3 \%$ goat serum, tissue was incubated with the primary monoclonal anti-KHV antibody (P14, Aquatic Diagnostic). After three washes with Tris-buffered saline (TBST), followed by addition of the secondary antibody (goat anti-mouse $\mathrm{IgG}$ ) peroxidase activity was detected with 32-diaminobenzidine-tetrahydrochloride (DAB, Abcam). To investigate the specificity of these reactions, isotype control as negative control and a known infected individual as positive control were used. Finally, the samples were examined under optical microscopy (AxioCam MR, Carl Zeiss, Oberkochen, Germany).

\section{Detection of KHV}

KHV DNA was detected using the CyHV-3-specific PCR (OIE, 2013). DNA was extracted from gills and kidneys using Qiagen DNeasy Blood \& Tissue kit, and PCR amplification was performed using specific primers (Table 2). The PCR products were subjected to electrophoresis in an agarose gel (1\%), visualized by UV transillumination, and photographed.

\section{RESULTS}

Fig. 1 shows the cumulative mortality from the KHV challenge-test. We first detected diseased fish at 3 days post infection (p.i.), which were floating on the water surface in the culture tank. Mortality started between day 5 and day 7 p.i. depending on the group. The mortality of the uninfected controls was $0 \%$ throughout the experiment, but the infected KK group reached 28\% by day 40 p.i. The cumulative mortality was $8 \%$ in the KR group and 6\% in the RK group. Previous study observed that the KHV infected juvenile red common carp had 100\% survival by day 50

Table 2. Primers used for KHV detection in this study

\begin{tabular}{cccc}
\hline \hline Primer & Sequence & Product size (bp) & Reference \\
\hline TK F & 5'-GGGTTACCTGTACGAG-3' & 409 & OIE (2013) \\
TK R & 5'-CACCCAGTAGATTATGC-3' & & \\
\hline Sphl-5 F & 5'-GACACCACATCTGCAAGGAG-3' & \multirow{2}{*}{292} & OIE (2013) \\
Sphl-5 R & 5'-GACACATGTTACAATGGTCGC-3' & & \\
\hline
\end{tabular}

$\mathrm{KHV}$, koi herpesvirus. 


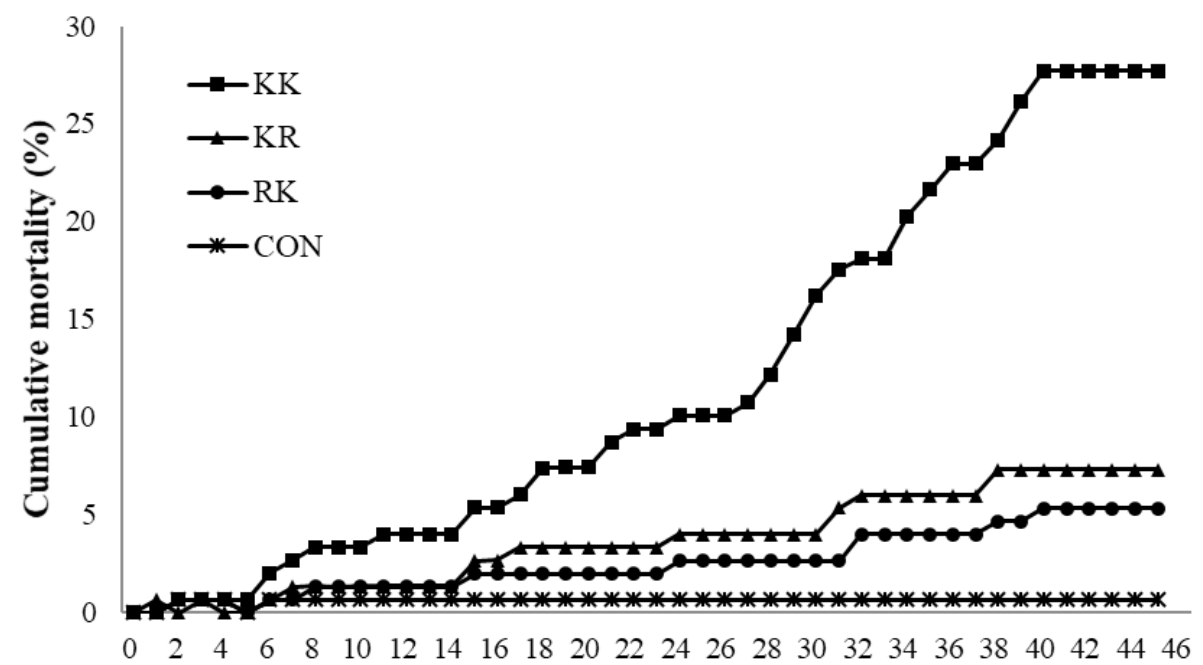

Fig. 1. Cumulative mortality of KK, KR, and RK fish infected with the Cyprinid herpesvirus-3 (CyHV-3), and of uninfected KK fish (CON). The experiment was stopped at day 45, and dead fish were collected daily until experiment ceased. The RK was the most resistant, while KK was the most sensitive. KK, koixkoi ; KR, koixred common carp; RK, red common carp×koi.

p.i. but not juvenile koi (data not shown). Diseased fish had hemorrhages, mucus production, and necrosis in gills, and these were more severe in the KK than in the RK and KR (Fig. 2). We observed no abnormalities on the body surface and gills of RK fish (Fig. 2).

Our PCR experiments indicated the presence of KHV DNA in all dead fish (Fig. 3A). In particular, a KHV-specific DNA (TK and SphI-5) was detected in the gills and kidneys of dead fish (n=3) from KK group (Fig. 3B).

There were also histopathological changes in the gills of infected fish (Fig. 4). In KK fish infected KHV, fusion in gill lamellae with swollen were observed and the gill showed necrosis of the epithelial cells on day 9 (Fig. 4B). Examination of sectioned and stained kidney from KHV-infected KK revealed severe infiltration of lymphocytic-cells at day 6 p.i., with necrosis of the renal tubules and especially severe pathology (Fig. 5A). IHC analysis revealed the KHV antigen was present in the kidney (Fig. 5B). KHV proteins were detected at high levels in the KK group, whereas they
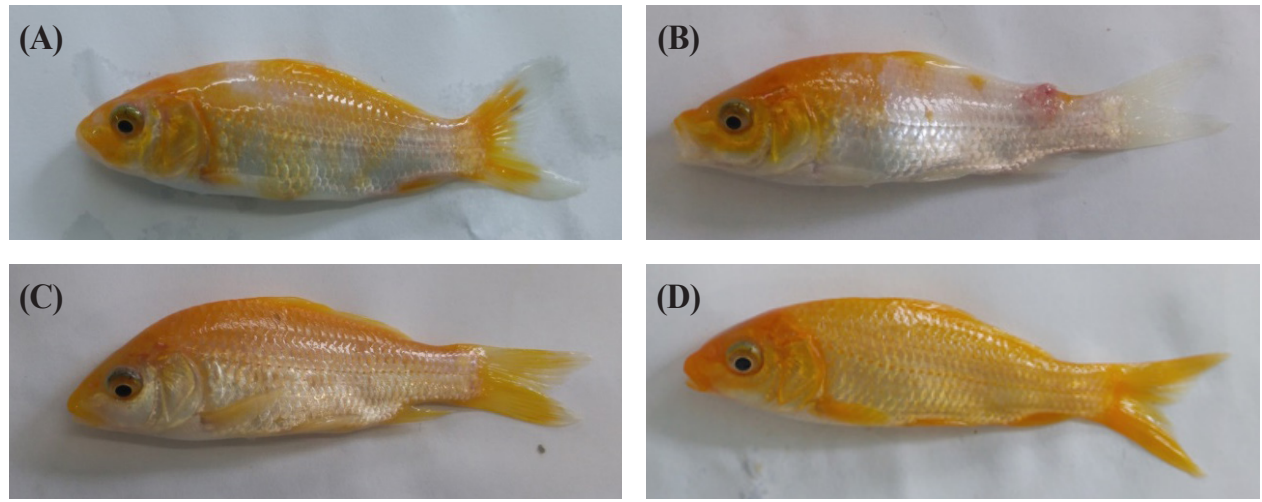

Fig. 2. Clinical signs of infection by KHV in representative fish from each group at 6 days. Uninfected KK fish (A) were normal, but there were signs of severe infection (increased mucous production, hemorrhages in the fins, and enophthalmos) in KK (B). KR fish (C) and RK fish (D) had intermediate levels of infection. KHV, koi herpesvirus. KK, koixkoi; KR, koixred common carp; RK, red common carp $\times$ koi. 
(A)

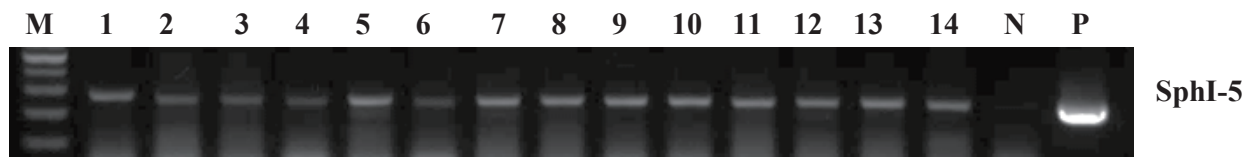

(B)
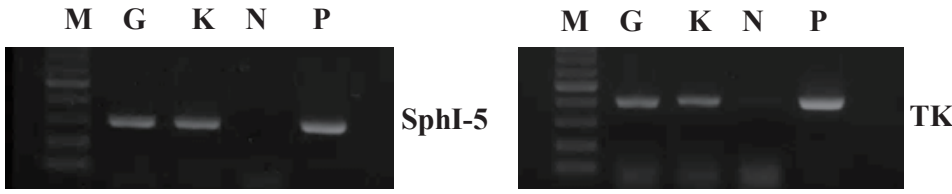

Fig. 3. Results from the PCR assay of CyHV-3 infected fish. (A) PCR detection of cyprinid herpesvirus-3 (CyHV-3) DNA in gills of challenge fish. Lane M: 100 bp DNA ladder, lane P: positive control, lane N: negative control, lanes 1-9: gills of 9 different KK fish, lanes 10-12: gills of 3 different KR fish, lanes 13-14: gills of 2 different RK fish. (B) Detection of CyHV-3 DNA in gills and kidneys of KK group. PCR, polymerase chain reaction; KK, koixkoi; KR, koixred common carp; RK, red common carp×koi; Lane M, 100 bp DNA ladder; lane N, negative control; lane P, positive control; lane G, gill; lane K, kidney.
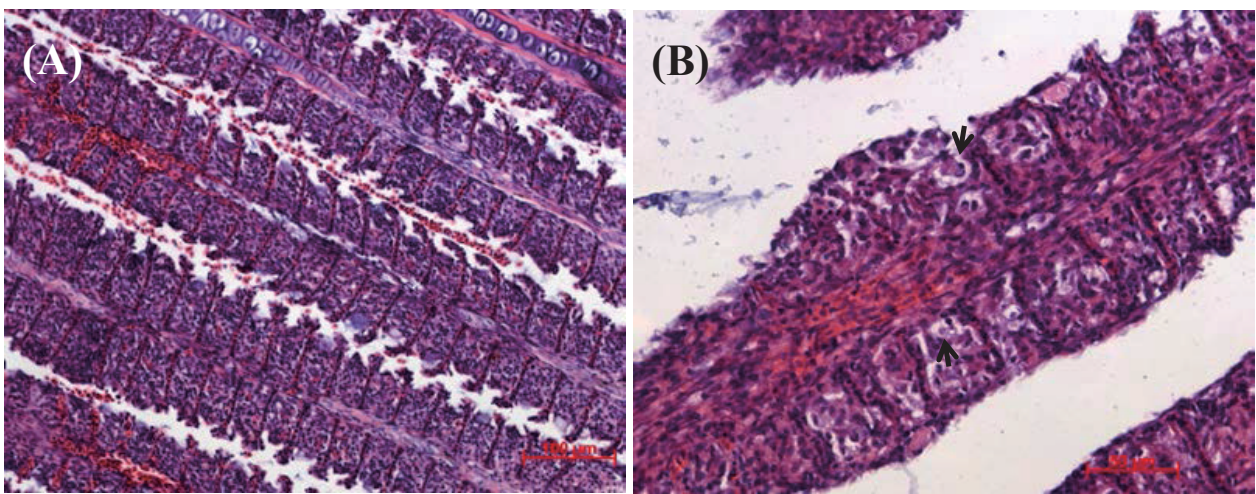

Fig. 4. Histological sections of the gills of CyHV-3-infected fish after 9 days (KK fish). Gill showing fusion in the lamella (A) and necrosis in epithelial cells.

(B). H-E. Scale bar: A; $100 \mu \mathrm{m}, \mathrm{B} ; 50 \mu \mathrm{m}$. Arows necrotic cells. CyHV-3, cyprinid herpesvirus-3; KK, koixkoi.

(A)
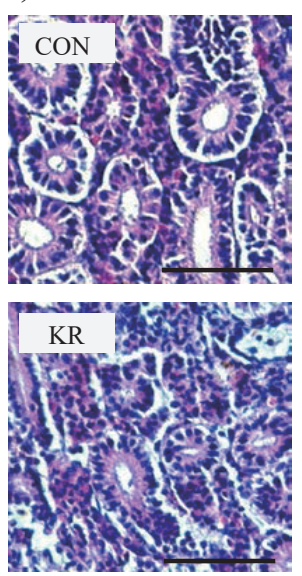

(B)
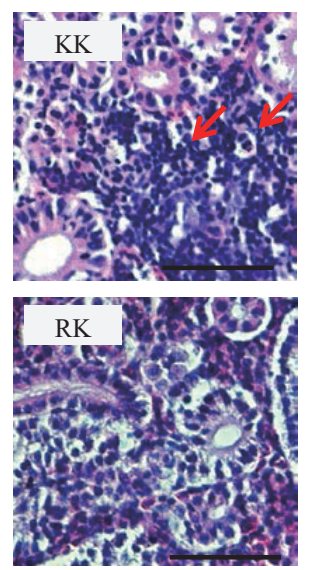
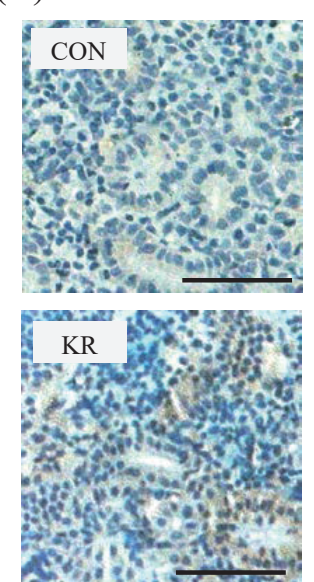
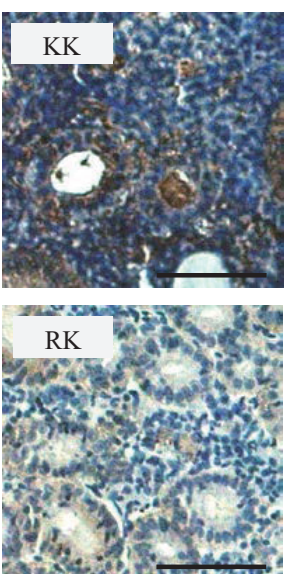

Fig. 5. Histopathology and immunohistochemistry of KHV infected kidney at 6 days after infection with of CyHV-3. H-E staining (A) reveals an inflammatory infiltrate consisting of lymphocytes (arrows). The KHV antigen (B) was present in leukocytes within the renal interstitium. Scale bar: $50 \mu m$. KHV, koi herpesvirus. KK, koi×koi; KR, koixred common carp; RK, red common carp×koi; CON, uninfected KK fish; CyHV-3, cyprinid herpesvirus-3. 
were detected at low level in the KR and RK group. The KHV protein was more abundant in the cytoplasm than the nuclei of the large polygonal cells infiltrating the renal interstitium. There was no reactivity in the tissues of uninfected control fish (Fig. 5B).

\section{DISCUSSION}

Previous researchers proposed cross-breeding as a potential method to improve fish resistance to KHV disease (Shapira et al., 2005; Hedrick et al., 2006), and studies of the genetics of disease resistance in fish support this strategy (Chevassus \& Dorson 1990). Previous studies have established hybrid cultured carps (Bergmann et al., 2010b). In particular, Israeli carp strains (Dor70 and Nasice) that were crossbred with a native Czech strain (Sasson) had significantly higher survival rates following KHV infection (64\% and 69\%) than either parental strain (Dor-70: 28\%; Nasice: 9\%) (Shapira et al., 2005). Similar experiments in the UK showed that crossbreeding carp with a 'wild' strain originating from the Amor or Duna Rivers in Hungary produced carp that were more resistant to KHV than domesticated carp (Dixon et al., 2009). Other studies examined koixcrucian carp (Carassius carassius) hybrids and koixgoldfish hybrids, and reported that both hybrids showed signs of KHV. Even though the koixcrucian carp hybrid had similar mortality levels as pure carp following KHV-I infection ( $91 \%$ and $100 \%$, respectively), the koixgoldfish hybrid had reduced mortality (35\%; Bergmann et al., 2010b). Little is known about the resistance of koi and red common carp cross. In the current study, we crossbred koi and red common carp and evaluated their resistance to KHV. The results show that all tested hybrid fish had improved resistance to KHV relative to KK fish, but the hybrids also had some susceptibility to KHV.

Our results are inconsistent with the findings of Bergman et al. (2009) and Hedrick et al. (2006), who demonstrated high susceptibility of koixgoldfish hybrids (35\% to KHV-I and $42 \%$ to KHV-E). Our results demonstrated a higher survival rate by RK cross (94\%) and KR cross (92\%) than $\mathrm{KK}$ fish (72\%) at 40 days after intraperitoneal injection of the KHV virus. The CyHV-3 can be subdivided in 3 main genotypes: one from Japan (KHV-J), one from Israel (KHV-I), and one from the United States and Europe (KHV-U). In this study, we purchased viral DNA from the UK (VR-1592). The survival rate in our experiments (KK: 72\%) may differ from that reported by other groups (koi and carp: 10\%-30\%) due to the use of different KHV genotypes, different infection methods, or different fish strains or breeding methods. Other studies of virus infections of carppure lines or hybrids-indicated the presence of different genetic sources of resistance due to the large range of survival rates (0\%-98\%) (Dixon et al., 2009; Rakus et al., 2009; Shapira et al., 2005)

The presence of CyHV-3 can be verified by amplification of the TK gene using PCR (Bercovier et al., 2005), an ELISA (Adkison et al., 2005), real-time PCR, or nested-PCR (Bergmann et al., 2010a). We performed PCR to confirm the presence of CyHV-3 (OIE, 2013), and also performed IHC in gill and kidney tissues. We found viral DNA in all dead fish, and our IHC assay detected the $\mathrm{KHV}$ antigen in the kidneys of all infected fish. The presence this antigen is a reliable indicator of exposure to the virus. And also, the CyHV-3 was re-isolated from the kidney of infected fish. The CyHV-3 virus confirmed by the presence of CPE and was detected by PCR on day 5 (data not shown).

The major histocompatibility complex (MHC) is an important component of disease resistance. Many studies have established an association between MHC diversity and resistance to pathogens (Rakus et al., 2009; Li et al., 2011; Zhao et al., 2012). In common carp, MHC class II B genes may be markers for resistance to CyHV-3 (Rakus et al., 2009), and in purse red common carp (Cyprinus carpio), MHC class II $\alpha$ alleles may be associated with resistance to Aeromonas hydrophila (Liu 
et al., 2014). However, the mechanism of KHV resistance in RK and KR hybrids is unknown. In our previous study, we reported that Interleukin (IL)-12 p35 and Toll-like receptor (TLR) 9 were significantly high expressed on $48 \mathrm{~h}$ p.i in RK (Hwang et al., 2017) and our future studies will seek to identify candidate genes for KHV resistance in these cross groups using 2-dimensional electrophoresis and proteomics.

In conclusion, our results indicate that two koi cross -KR and -RK were more resistant KHV than KK fish. Use of such cross may therefore be a possible approach to reduce serious mortality due to KHV infection.

\section{REFERENCES}

Aoki T, Hirono I, Kurokawa K, Fukuda, Nahary R, Eldar A, Davison AJ, Waltzek TB, Bercovier B, Hedrick RP (2007) Genome sequences of three koi herpesvirus isolates representing the expending distribution of an emerging disease threatening koi and common carp worldwide.J Virol 81:5058-5065.

Aoki T, Takanoa T, Unajaka S, Takagi M, Kim YR, Park SB, Kondoa H, Hironoa I, Saito-Taki T, Hikimac JI, Jung TS (2011) Generation of monoclonal antibodies specific for ORF68 of koi herpesvirus. Comp Immunol Microbiol Infect Dis 34:209-216.

Bercovier H, Fishman Y, Nahary R, Sinai S, Zlotkin A, Eyngor M, Gilad O, Eldar A, Hedrick RP (2005) Cloning of the koi herpesvirus (KHV) gene encoding thymidine kinase and its use for highly sensitive PCR based diagnosis. BMC Microbiol 5:13-22.

Bergmann SM, Riechart M, Fichtner D, Lee P, Kempter J (2010a) Investigation on the Disgnostic sensitivity of molecular tools used for detection of koi herpes virus. J Virol Methods 163:229233.

Bergmann SM, Sadowski J, Kiełpiński M, Bartłomiejczyk M, Fichtner D, Riebe R, Lenk M, Kempter J (2010b) Susceptibility of koixcrucian carp and koixgoldfish hybrids to koi herpesvirus (KHV) and development of KHV disease (KHVD).J Fish Dis 33:267-272.

Bergmann SM, Schütze H, Fischer U, Fichtner D, Riechardt M, Meyer K, Schrudde, Kempter J (2009) Detection of koi herpes virus (KHV) genome in apparently healthy fish. Bull Eur Assoc Fish Pathol 29:145-152.

Bretzinger A, Fischer-Scherl T, Oumouna M, Hoffmann R, Truyen U (1999) Mass mortalities in koi carp, Cyprinus carpio, associated with gill and skin disease. Bull Eur Assoc Fish Pathol 19:182-199.

Cheng L, Chen CY, Tsai MA, Wang PC, Hsu JP, Chern R, Chen SC (2011) Koi herpesvirus epizootic in cultured carp and koi, Cyprinus carpio L., in Taiwan.J Fish Dis 34:547-554.

Chevassus B, Dorson M (1990) Genetics of resistance to disease in fishes. Aquac 85:83-107.

Cho MY, Won KM, Kim JW, Jee BY, Park MA, Hong S (2014) Detection of koi herpesvirus (KHV) in healthy cyprinid stock. Dis Aquat Org 112:29-36.

Costes B, Raj VS, Michel B, Fournier G, Thirion M, Gillet L, Mast J, Lieffrig F, Bremont M, Vanderplasschen A (2009) The major portal of entry of Koi herpesvirus in Cyprinus carpio is the Skin.J Virol 83:2819-2830.

Dishon A, Perelberg A, Bishara-Shieban J, Ilouze M, Davidovich, M, Werker, S, Kotler M. (2005) Detection of carp interstitial nephritis and gill necrosis virus in fish droppings. Appl Environ Microbiol 71:7285-7291.

Dixon PF, Joiner CL, Way K, Reese RA, Jeney G, Jeney Z (2009) Comparison of the resistance of selected families of a common carp, Cyprinus carpio L., to koi herpesvirus: preliminary study. J 
Fish Dis 32:1035-1039.

Dong C, Weng S, Li W, Li X, Yi Y, Liang Q, He J (2011) Characterization of a new cell line from caudal fin of koi, Cyprinus carpio koi, and first isolation of cyprinid herpesvirus 3 in China. Virus Res 161:140-149.

Gilad O, Yun S, Andree KB, Adkison MA, Zlotkin A, Bercovier H, Eldar A, Hedrick RP (2002) Initial characteristics of koi herpesvirus and development of a polymerase chain reaction assay to detect the virus in koi, Cyprinus carpio koi. Dis Aquat Org 48:101-108.

Gilad O, Yun S, Zagmutt-Vergara FJ, Leutenegger CM, Bercovier HV, Hedrick RP (2004) Concentrations of a koi herpesvirus (KHV) tissues of experimentally-infected Cyprinus carpio koi as assessed by real-time TaqMan PCR. Dis Aquat Org 60:179-187.

Gomez DK, Joh SJ, Jang H, Shin SP, Choresca CH Jr, Han JE, Kim JH, Jun JW, Park SC (2011) Detection of koi herpesvirus (KHV) from koi (Cyprinus carpio koi) broodstock in South Korea. Aquac 311:42-47.

Haenen OLM, Way K, Bergmann SM, Ariel E (2004). The emergence of koi herpesvirus and its significance to European aquaculture. Bull Eur Assoc Fish Pathol 24:293-307.

Haramoto E, Kitajima M, Katayama H, Ito T, Ohgaki S (2009) Development of virus concentration methods for detection of koi herpesvirus in water.J Fish Dis 32:297-300.

Hedrick RP, Gilad O, Yun SC, McDowell TS, Waltzek TB, Kelley GO, Adkison MA (2005) Initial isolation and characterization of a herpes-like virus (KHV) from koi and common carp. Bull Fish Res Agency S2: 1-7.

Hedrick RP, Gilad O, Yun S, Spangenberg JV, Marty, GD, Nordhausen RW, Kebus MJ, Bercovier H, Eldar A (2000) A herpesvirus associated with mass mortality of juvenile and adult koi, a strain of common carp. J Aquat Anim Health 12:44-57.

Hedrick RP, Waltzek TB, McDowell TS (2006) Susceptibility of koi carp, common carp, Goldfish, and goldfish $\times$ common carp hybrids to cyprinid herpesvirus- 2 and herpesvirus-3.J Aquat Anim Health 18:26-34.

Hwang JA, Kim JE, Kim HS, Lee JH (2017) Immune response to koi herpesvirus (KHV) of koi and koixred common carp (Cyprinus carpio). Dev Reprod 21:361-370.

ICTV (2020) International Committee on Taxonomy of Viruses ICTV. Available from: http:// www.ictvonline.org. Accessed at September 28, 2020.

Liu J, Liu ZZ, Zhao XJ, Wang CH (2014) MHC class IIa alleles associated with resistence to Aeromonas hydrophila in purse red common carp, Cyprinus carpio Linnaeus.J Fish Dis 37:571575.

Li XS, Liu ZZ, Zhao XJ, Ma XQ, Feng W, Wang CH (2011) Major histocompatibility complex $\mathrm{DAB}$ allele polymorphism and its association with resistance/susceptibility to Aeromonas hydrophila in "whole red" color patterns of Cyprinus carpio var. color.J Fish Chin 35:1293-1301.

Minamoto T, Honjo MN, Yamanaka H, Uchii K, Kawabata Z (2012) Nationwide Cyprinid herpesvirus 3 contamination in natural rivers of Japan. Res Vet Sci 93:508-514.

OIE (2007) Koi herpesvirus disease. In: Manual of Diagnostic Tests for Aquatic Animals. World Organisation for Animal Health, Paris, France.

OIE (2013) Manual of Diagnostic Tests for Aquatic Animals. Office International Des Epizooties, Paris, France.

Rahmati-Holasoo H, Zargar A, Ahmadivand S, Shokrpoor S, Ezhari S, Ebrahimzadeh Mousavi HA (2016) First detection of koi herpesvirus from koi, Cyprinus carpio L. experiencing mass mortalities in Iran: clinical, histopathological and molecular study.J Fish Dis 39:1153-1163.

Pikarsky E, Ronen A, Abramowitz J, Levavi-Sivan B, Hutoran M, Shapira Y, Steinitz M, Perelberg A, SofferD, Kotler M (2004) Pathogenesis of acute viral disease in fish induced by the carp 
interstitial nephritis and gill necrosis virus.J Virol 78:9544-9551.

Rakus KE, Wiegertjes GF, Jurecka PM, Walker PD, Pilarczyk A, Irnazarow I (2009) Major histocompatibility $(\mathrm{MH})$ class II B gene polymorphism influences disease resistance of common carp (Cyprinus carpio L.). Aquaculture 288:44-50.

Roizman B, Pellet P (2001) The family herpesviridae: a brief introduction. In: Knipe DM, Howley PM (eds), Fields Virology. 4th ed. Lippincott Williams \& Wilkins, Philadelphia, PA, pp 23812397.

Sano M, Ito T, Kurita J, Miwa S, Lida T (2005) Diagnosis of koi Herpesvirus (KHV) disease in Japan. Bull Fish Res Agency S2 :59-64.

Sano M, Ito T, Kurita J, Yanai T, Watanabe N, Miwa S, Lida T (2004) First detection of koi herpesvirus in cultured common carp Cyprinus carpio in Japan. Fish Pathol 39:165-167.

Shapira Y, Magen Y, Zak T, Ktler M, Hulata G, Levavi-Sivan B (2005) Differential resistance to koi herpes virus (KHV)/carp interstitial nephritis and gill necrosis virus (CNGV) among common carp (Cyprinus carpio L.) strains and crossbreds. Aquac 245:1-11.

Tu C, Weng MC, Shiau JR, Lin SY (2004) Detection of koi herpesvirus in koi Cyprinus carpio in Taiwan. Fish Pathol 39:109-110.

Wang CH, Li SF, Xiang SP, Wang J, Liu ZG, Pang ZY, Duan JP, Xu ZB (2006) Additive, dominance genetic effects for growth-related traits in common carp, Cyprinus carpio L. Aquac Res 37:1481-1486.

Zhao XJ, Liu ZZ, Li XS, Wang Y, Wang CH (2012) Major histocompatibility complex class II B allele polymorphism and its association with resistance/susceptibility to Aeromonas hydrophila in the "whole white" color patterns of Cyprinus carpio var. color.J Fish Chin 19:399-407. 
